\title{
THE ROLE OF CHAR FORMATION IN EQUILIBRIUM MODELING OF GASIFICATION PROCESSES
}

\author{
Vinícius F. Ramos ${ }^{1 *}$, Esly F. da Costa Junior ${ }^{1}$, Andréa O. S. da Costa ${ }^{1}$ \\ ${ }^{1 *}$ Correpondig author. Universidade Federal de Minas Gerais/ Belo Horizonte - MG, Brasil. \\ E-mail: viniciusramos92@gmail.com | ORCID ID: https://orcid.org/0000-0001-5908-8025
}

\section{KEYWORDS}

char formation, gasification, Gibbs energy minimization, modeling.

\begin{abstract}
This work aims to develop and validate a model based on chemical equilibrium to predict the composition of syngas produced by gasification of woody biomass (sawdust). The model uses Gibbs Energy minimization to evaluate the composition of the system in chemical equilibrium. The results are validated by comparison between experimental data from a gasification experiment and those of other similar models in the literature. The study shows good agreement among experimental results and elucidates the role of solid unburned carbon in such systems, which is present in considerable amount. It can be concluded that equilibrium models can be used to predict carbon conversion in gasification systems.
\end{abstract}

\section{INTRODUCTION}

Recent efforts to reduce the human impact on climate change, especially the reduction of $\mathrm{CO}_{2}$ emissions, include the replacement of fossil fuels, such as oil and coal, with renewable and less polluting energy sources. These efforts promoted increasing interest in the usage of biomass fuels to produce electricity. Biomass can be defined as any carbonaceous material, such as wood, straw, or sewage sludge, and is advantageous in that there is no net increase in $\mathrm{CO}_{2}$ emissions due to biomass combustion because $\mathrm{CO}_{2}$ produced from the combustion is consumed during plant growth (Roni et al., 2017). The development and use of more advanced technologies involving biomass are important to reduce the dependence on fossil fuel resources, especially in rural areas, where biomass is readily available (Saidur et al., 2011; Demirbas, 2005). Direct combustion of biomass is the most used thermochemical process to obtain heat from biomass.

However, for non-woody fuels in small-scale systems, direct combustion is hindered because of low energy efficiency and high pollutant emission (Verma et al., 2011). Gasification is a process in which biomass is heated up to 800 $1000{ }^{\circ} \mathrm{C}$ and is transformed by devolatilization and chemical reactions into syngas composed mainly of $\mathrm{CO}, \mathrm{CO}_{2}, \mathrm{H}_{2}$, and $\mathrm{CH}_{4}$ (Saidur et al., 2011). Mathematical modeling is a useful tool for the investigation of such thermal processes, as it can be used to study a given system without the need to run several experimental tests (Fournel et al., 2015). The models can be built by studying the system behavior through equations that describe the physical and chemical phenomena involved in the process, such as Computational Fluid Dynamics or transient models (Silveira et al., 2017; Rajh et al., 2016; Siqueira et al., 2012). Although these types of models can describe several phenomena, they require considerable detailed information about the system and computational resources. Thermodynamic equilibrium models have an advantage in this scenario, as they do not require a large database or detailed information about the chemical reactions occurring in the system. These types of models require the ultimate analysis of biomass ( $\mathrm{C}, \mathrm{H}, \mathrm{O}, \mathrm{N}, \mathrm{S}$, and moisture contents), mass flows of fuel and air, and system temperature and pressure as inputs (Baratieri et al., 2008).

Although the equilibrium is not reached in real cases, these models can predict the composition of syngas produced through gasification processes with satisfactory accuracy (Gambarotta et al., 2017). The models can be based on Gibbs Energy minimization (Fournel et al., 2015; Mendiburu et al., 2014; Jarungthammachote \& Dutta, 2008) or use of equilibrium constants (Aydin et al., 2017; Mozafari et al., 2017; Jarungthammachote \& Dutta, 2007). Altafini, Wander, and Barreto performed gasification tests using Pinus Elliotis sawdust as fuel (Altafini et al., 2003). In order to model such experimental test, Fournel et al. and Jarungthammachote \& Dutta developed computational models based on thermodynamic equilibrium to predict the formation of syngas. The predicted composition was compared to the experimental results (Fournel et al., 2015; Jarungthammachote \& Dutta, 2008). Because modeling involves the formation of gaseous

\footnotetext{
${ }^{1}$ Universidade Federal de Minas Gerais/ Belo Horizonte - MG, Brasil.
} 
compounds and thermochemical processes degrade the biomass components into simpler ones, the species of biomass does not significantly interfere in modeling; thus, the results vary according to the composition and moisture content of biomass.

This work aims to build and validate a thermodynamic model to predict the production of $\mathrm{CO}, \mathrm{CO}_{2}, \mathrm{H}_{2}$, and $\mathrm{CH}_{4}$ based on Gibbs energy minimization, considering the formation of $\mathrm{C}_{(\mathrm{s})}$, and to verify the role of the unburned carbon on the gasification yield, since the two cited models only took into account the gaseous products of the gasification.

\section{MATERIAL AND METHODS}

Biomass is defined as a material composed of four elements and is considered to have the chemical composition of $\mathrm{CH}_{\mathrm{a}} \mathrm{O}_{\mathrm{b}} \mathrm{N}_{\mathrm{c}}$. Because thermochemical conversion processes involve several different reactions and intermediate compounds, the gasification reaction can be simplified considering only the main compounds present in the media. The equilibrium media can be represented by [eq. ((1)]:

Where:

$$
\mathrm{CH}_{\mathrm{a}} \mathrm{O}_{b} \mathrm{~N}_{c}+\mathrm{w} \mathrm{H} \mathrm{H}_{2} \mathrm{O}+\mathrm{r}\left(\mathrm{O}_{2}+3.76 \mathrm{~N}_{2}\right)=\mathrm{n}_{\mathrm{H}_{2}} \mathrm{H}_{2}+\mathrm{n}_{\mathrm{CH}_{4}} \mathrm{CH}_{4}+\mathrm{n}_{\mathrm{CO}} \mathrm{CO}+\mathrm{n}_{\mathrm{co}_{2}} \mathrm{CO}_{2}+\mathrm{n}_{\mathrm{H}_{2} \mathrm{O}} \mathrm{H}_{2} \mathrm{O}+\mathrm{n}_{\mathrm{N}_{2}} \mathrm{~N}_{2}
$$

$\mathrm{a}, \mathrm{b}$, and $\mathrm{c}$ are the number of atoms of hydrogen, oxygen, and nitrogen in biomass $\left(\mathrm{kmol}_{\mathrm{ELEMENT}} / \mathrm{kmol} \mathrm{C}\right)$;

$\mathrm{w}$ is the $\mathrm{wt} \%$ of moisture in biomass $\left(\mathrm{kmol}_{\mathrm{H} 2 \mathrm{O}} / \mathrm{kmol}_{\text {FEEDSTOCK }}\right)$;

$\mathrm{r}$ is the amount of air supplied to the process $\left(\mathrm{kmol}_{\mathrm{AIR}} / \mathrm{kmol}_{\text {FEEDSTOCK }}\right)$, and

$\mathrm{n}_{\mathrm{i}}$ is the number of moles of species $\mathrm{i}$ in the system.

The moisture and molar composition of biomass were obtained experimentally by proximate and ultimate analyses, and the air-to-fuel ratio (AFR) was obtained as a parameter of the experiment. Another proposed model considers the formation of char $\left(\mathrm{C}_{(\mathrm{s})}\right)$ as described by [eq. (2)].

$$
\mathrm{CH}_{a} \mathrm{O}_{b} \mathrm{~N}_{c}+\mathrm{w} \mathrm{H} \mathrm{H}_{2} \mathrm{O}+\mathrm{r}\left(\mathrm{O}_{2}+3.76 \mathrm{~N}_{2}\right)=\mathrm{n}_{\mathrm{H}_{2}} \mathrm{H}_{2}+\mathrm{n}_{\mathrm{CH}_{4}} \mathrm{CH}_{4}+\mathrm{n}_{\mathrm{CO}} \mathrm{CO}+\mathrm{n}_{\mathrm{co}_{2}} \mathrm{CO}_{2}+\mathrm{n}_{\mathrm{H}_{2} \mathrm{O}} \mathrm{H}_{2} \mathrm{O}+\mathrm{n}_{\mathrm{N}_{2}} \mathrm{~N}_{2}+\mathrm{n}_{\mathrm{C}_{(\mathrm{s})}} \mathrm{C}_{(\mathrm{s})}
$$

TABLE 1. Biomass properties used as input for the models. (Altafini et al., 2003).

\begin{tabular}{ll}
\hline Input values & Altafini et al. (2003) \\
\hline Carbon $(\mathrm{wt} \%)$ & 52.05 \\
Hydrogen $(\mathrm{wt} \%)$ & 6.08 \\
Oxygen $(\mathrm{wt} \%)$ & 41.59 \\
Nitrogen $(\mathrm{wt} \%)$ & 0.28 \\
Higher heating value $(\mathrm{MJ} / \mathrm{kg})$ & 20.4 \\
Moisture content $(\mathrm{wt} \%, \mathrm{waf})$ & 10.0 \\
Biomass feed rate $(\mathrm{kg} / \mathrm{h})$ & 12.6 \\
Air/biomass mass ratio $\left(\mathrm{kg}\right.$ AIR $\left./ \mathrm{kg}_{\mathrm{BM}}\right)$ & 1.96 \\
Gasification temperature $(\mathrm{K})$ & 1073 \\
\hline
\end{tabular}

Note: waf $=$ wet and ash-free basis.

The biomass and gasification data of the experimental system used by Altafini, Wander and Barreto are shown in Table 1 (Altafini et al., 2003).

\section{Gibbs energy minimization}

When a closed system is in chemical equilibrium, its Gibbs energy $(\mathrm{G})$ reaches a minimum value (Smith et al., 2017). For a system with $F$ and $N_{j}$ species in phase $j$, the total Gibbs energy of the system is the sum of the contribution of each species-specific Gibbs energy. It is given by the chemical potential of each species $i$ in phase $j$ $\left(\mu_{\mathrm{i}, \mathrm{j}}\right)$ as follows.

$$
G=\sum_{j=1}^{F} \sum_{i=1}^{N} n_{i, j} \cdot \mu_{i, j}
$$

Solving [eq. (3)] for a minimum $G$ value implies determination of the number of each species in the equilibrium media $\left(\mathrm{n}_{\mathrm{i}, \mathrm{j}}\right)$ and prediction of the composition of the system (Sundman et al., 2015). For a system composed of ideal gases at atmospheric pressure, $\mu_{i, j}=\Delta G_{f_{i, j}}^{o}+R \cdot T \cdot \ln \left(y_{i, j}\right)$

Where:

$\Delta \mathrm{G}_{\mathrm{f}_{\mathrm{i}, \mathrm{j}}}^{\mathrm{o}}$ is the standard Gibbs energy of the formation of species $\mathrm{i}(\mathrm{kJ} / \mathrm{mol})$ at the equilibrium temperature and pressure;

$\mathrm{R}$ is the universal gas constant $(8.314 \mathrm{~J} / \mathrm{mol} \mathrm{K})$, and $\mathrm{y}_{\mathrm{i}, \mathrm{j}}$ is the mole fraction of gaseous species $\mathrm{i}$ in phase $\mathrm{j}$. The equation for the Gibbs energy becomes.

$G^{\prime}=\sum_{j=1}^{F} \sum_{i=1}^{N} n_{i, j} \cdot \Delta G_{f_{i, j}}^{o}+\sum_{j=1}^{F} \sum_{i=1}^{N} n_{i, j} \cdot$ R. T. $\ln \left(\frac{n_{i, j}}{n_{t o t, j}}\right)$

Where:

$\mathrm{n}_{\mathrm{tot}, \mathrm{j}}$ is the total number of moles in phase $\mathrm{j}$, and

$\Delta G_{f_{i, j}}^{o}$ is the standard Gibbs energy of formation of species $i$ in phase $j$, which is defined by:

$$
\Delta \mathrm{G}_{\mathrm{f}_{\mathrm{i}, \mathrm{j}}}^{\mathrm{o}}=\Delta \mathrm{H}_{\mathrm{f}_{\mathrm{i}, \mathrm{j}}}^{\mathrm{o}}-\mathrm{T} \cdot \Delta \mathrm{S}_{\mathrm{f}_{\mathrm{i}, \mathrm{j}}}^{\mathrm{o}}
$$


Where:

$\Delta \mathrm{H}_{\mathrm{f}_{\mathrm{i}, \mathrm{j}}}^{\mathrm{o}}$ and $\Delta \mathrm{S}_{\mathrm{f}_{\mathrm{i}, \mathrm{j}}}^{\mathrm{o}}$ are the standard enthalpy and entropy of formation at the equilibrium $\mathrm{T}$ and atmospheric pressure of each species-specific Gibbs energy, respectively, which can be calculated by eqs (7) and (8):

$$
\begin{gathered}
\Delta \mathrm{H}^{\mathrm{o}}=\Delta \mathrm{H}_{\mathrm{f}}^{\mathrm{o}}\left(\mathrm{T}_{0}\right)+\int_{\mathrm{T}_{0}}^{\mathrm{T}} \mathrm{C}_{\mathrm{p}} \cdot \partial \mathrm{T} \\
\Delta \mathrm{S}^{\mathrm{o}}=\Delta \mathrm{S}_{\mathrm{f}}^{\mathrm{o}}\left(\mathrm{T}_{0}\right)+\int_{\mathrm{T}_{0}}^{\mathrm{T}}\left(\frac{\mathrm{C}_{\mathrm{p}}}{\mathrm{T}}\right) \cdot \partial \mathrm{T}
\end{gathered}
$$

Where:

$\mathrm{C}_{\mathrm{p}}$ is the heat capacity at constant pressure of the compounds, and

$\mathrm{T}_{0}$ is the inlet temperature of the reactants $(\mathrm{K})$.

The heat capacity is a function of the temperature, and its values can be given by a polynomial equation:

$$
\frac{\mathrm{C}_{\mathrm{p}}(T)}{\mathrm{R}}=A+\mathrm{B} \cdot \mathrm{T}+\mathrm{C} \cdot \mathrm{T}^{2}+\mathrm{D} \cdot \mathrm{T}^{3}+\mathrm{E} \cdot \mathrm{T}^{4}
$$

Where:

A, B, C, D, and E are empirical coefficients available in the literature.

In this study, the coefficients used were provided by NASA Technical Memorandum 4513 (Mcbride \& Reno, 1993. The calculation of the minimum Gibbs energy (Equation 10) consists of solving the equivalent optimization problem:

$$
\min \mathrm{G}^{\prime}=\sum_{\mathrm{j}=1}^{\mathrm{F}} \sum_{\mathrm{i}=1}^{\mathrm{N}} \mathrm{n}_{\mathrm{i}, \mathrm{j}} \cdot \Delta \mathrm{G}_{\mathrm{fi}, \mathrm{j}}^{\mathrm{o}}+\sum_{\mathrm{j}=1}^{\mathrm{F}} \sum_{\mathrm{i}=1}^{\mathrm{N}} \mathrm{n}_{\mathrm{i}, \mathrm{j}} \cdot \mathrm{R} \cdot \mathrm{T} \cdot \ln \left(\frac{\mathrm{n}_{\mathrm{i}, \mathrm{j}}}{\mathrm{n}_{\mathrm{tot}, \mathrm{j}}}\right)
$$

$$
\begin{aligned}
& \begin{array}{l}
\text { Subject } \\
\text { to: }
\end{array} \sum_{\mathrm{j}=1}^{\mathrm{F}} \sum_{\mathrm{i}=1}^{\mathrm{N}} \mathrm{a}_{\mathrm{k}, \mathrm{i}} \cdot \mathrm{n}_{\mathrm{i}, \mathrm{j}}=\mathrm{A}_{\mathrm{k}} \quad \mathrm{k}=1,2, \ldots, 4 \\
& 0 \leq \mathrm{n}_{\mathrm{i}, \mathrm{j}} \leq \mathrm{n}_{\text {tot }, \mathrm{j}}
\end{aligned}
$$

Where:

$a_{k, i}$ is the number of atoms of the k-th element in a mole of species $i$, and

$A_{k}$ is the total number of moles of the element in the reaction medium.

The first constraint (Equation 11) states the element mass conservation on the system, and the second constraint (Equation 12) denotes that the number of moles needs to be positive and less than the total number of moles of the species.

\section{Model assumptions}

In the development of $\mathrm{G}$ minimization, the following assumptions were made:

- Thermodynamic equilibrium was reached;
- Biomass and air enter the reaction media at $25{ }^{\circ} \mathrm{C}$ and $1 \mathrm{~atm}$;

- Average properties (temperature $=800{ }^{\circ} \mathrm{C}$ and pressure $=1 \mathrm{~atm}$ ) and mass flow of the inputs and outputs are constant;

- Only the species described by eqs (1) and (2) are formed during gasification;

- All gases behave as ideal gases;

- Ash in biomass is considered inert and is not present in the calculations.

- The char behavior in the system was modeled in two ways: (i) considered to be in a distinct solid phase, and the calculation proceeds as [eq. (10)] states; and (ii) considered as a participant in the gas phase, in a way that only one phase was considered in the system. With this assumption, [eq. (10)] becomes:

$$
\min \mathrm{G}^{\prime \prime}=\sum_{\mathrm{i}=1}^{\mathrm{N}} \mathrm{n}_{\mathrm{i}} \cdot \Delta \mathrm{G}_{\mathrm{f}_{\mathrm{i}}}^{\mathrm{o}}+\sum_{\mathrm{i}=1}^{\mathrm{N}} \mathrm{n}_{\mathrm{i}} \cdot \mathrm{R} \cdot \mathrm{T} \cdot \ln \left(\frac{\mathrm{n}_{\mathrm{i}}}{\mathrm{n}_{\mathrm{tot}}}\right)
$$

\section{Equilibrium Calculation}

The optimization problem was implemented in MATLAB, a commercial computational software. The optimization problem was solved by the fmincon routine inside the software. The routine uses the sequential quadratic programming method (SQP), which is suitable for constrained optimization problems. The function applies an interior-point algorithm, obtaining Lagrange multipliers applying the Karush-Kuhn-Tucker (KKT) conditions (Singh et al., 2016; Koukkari \& Pajarre, 2006).

\section{Model validation}

To validate the predicted syngas composition calculated by the developed model, the results were compared to the experimental data obtained by Altafini, Wander, and Barreto, who operated a downdraft gasifier using wood sawdust as fuel Altafini et al., 2003. The results were also compared to other similar models obtained by Jarungthammachote \& Dutra (2007), who developed a kinetic model considering species according to [eq. ((1)], and Fournel et al. (2015), who developed a Gibbs energy minimization model for the same system. A comparison was conducted between the two models described by eqs (1) and (2).

The modeling results were compared with the experimental values by determining the root-mean-square error (RMSE), defined by [eq. (14)]:

$$
\text { RMSE }=\sqrt{\frac{\sum_{\mathrm{i}}(\mathrm{y}-\hat{\mathrm{y}})^{2}}{\mathrm{~N}_{\mathrm{T}}}}
$$

Where:

$\mathrm{y}$ is the value from the experimental result, and

$\hat{y}$ is the predicted value from the model;

$\mathrm{N}_{\mathrm{T}}$ is the total number of data points. 
The char formation was validated by char conversion data obtained experimentally by Altafini, Wander and Barreto as well as by two correlations: one that predicts the $\mathrm{C}_{(\mathrm{s})}$ fraction among all the products in the system, given by (1- $\phi)$ in [eq. (15)] (Li et al., 2004), and one that estimates the amount of the total $C$ converted to the gas phase $(\beta)$, as given by [eq. (16)] (Aydin et al., 2017).

$\phi=1-\left(\frac{\mathrm{n}_{C_{(s)}}}{n_{\text {tot }}}\right)=0.32+0.82\left[1-\exp \left(-\frac{\mathrm{ER}}{0.229}\right)\right]$

$\beta=1-\left(\frac{\mathrm{n}_{C_{(s)}}}{n_{C_{t o t}}}\right)=0.25+0.75\left[1-\exp \left(-\frac{\mathrm{ER}}{0.23}\right)\right]$
Where:

ER (equivalence ratio) is the ratio of the air supplied to the system and the stoichiometric air requirement for complete combustion.

\section{RESULTS AND DISCUSSION}

\section{Predicted product distribution}

The results of the mole number of the species described by eqs (1) and (2), using data from Table 1 as the input, and optimized by the objective functions composed by eqs (10) and (13) are shown in Table 2.

TABLE 2. Composition of the reactive media.

\begin{tabular}{lllll}
\hline Species & $\begin{array}{l}\mathrm{n}_{\mathrm{i}} \\
(\text { Equations 1 and 10) }\end{array}$ & $\begin{array}{l}\mathrm{n}_{\mathrm{i}} \\
\text { (Equations 2 and 10) }\end{array}$ & $\begin{array}{l}\mathrm{n}_{\mathrm{i}} \\
\text { (Equations 1 and 13) }\end{array}$ & $\begin{array}{l}\mathrm{n}_{\mathrm{i}} \\
\text { (Equations 2 and 13) }\end{array}$ \\
\hline $\mathrm{CH}_{4}$ & 0.3 & 0 & 0.11 & 0.04 \\
$\mathrm{CO}$ & 106.26 & 5.8 & 106.58 & 77.26 \\
$\mathrm{CO}_{2}$ & 32.11 & 44.03 & 31.98 & 40.32 \\
$\mathrm{H}_{2}$ & 90.53 & 14.5 & 90.96 & 78.47 \\
$\mathrm{H}_{2} \mathrm{O}$ & 25.35 & 101.98 & 25.29 & 37.95 \\
$\mathrm{~N}_{2}$ & 165.52 & 165.52 & 165.52 & 165.52 \\
$\mathrm{C}(\mathrm{s})$ & - & 88.84 & - & 21.07 \\
\hline $\mathrm{n}_{\text {tot }}$ & 420.07 & 420.67 & 420.44 & 420.63 \\
\hline
\end{tabular}

The results show that the amount of char formation, although not very large, cannot be neglected, as the $\mathrm{C}_{(\mathrm{s})}$ accounts for the unburned carbon and indicates incomplete combustion, which lowers the energy efficiency of the process $\mathrm{Li}$ et al., 2004. When considering the char in a separate solid phase (objective function by Equation 10), there is a huge underestimation of the $\mathrm{CO}$ formation compared to the experimental value found by Altafini et al., (2003), as shown in Table.

\section{Prediction of syngas composition}

The previous model and the experimental data were expressed in terms of syngas composition $\left(\mathrm{CH}_{4}, \mathrm{CO}, \mathrm{CO}_{2}\right.$, $\mathrm{H}_{2}$, and $\mathrm{N}_{2}$ molar fractions). Therefore, since $\mathrm{H}_{2} \mathrm{O}$ and $\mathrm{C}_{(\mathrm{s})}$ are products, the modified molar fraction $\left(\mathrm{y}_{\mathrm{i}}\right)$ was calculated using [eq. (17)].

$$
\mathrm{y}_{\mathrm{i}}=\frac{\mathrm{n}_{\mathrm{i}}}{\mathrm{n}_{\mathrm{tot}}-\mathrm{n}_{\mathrm{H}_{2} \mathrm{o}}-\mathrm{n}_{\mathrm{C}_{(\mathrm{s})}}}
$$

Table 3 shows a comparison of the results of the experimental data obtained by Altafini et al., (2003) (first column), the gasification model made by other authors using the same experimental values (columns 2-4), and the models proposed in this study (columns 5-8). The results of columns 5 and 6 are the models developed without considering char formation, and columns 7 and 8 are the models developed considering char formation in the system.

In real gasification systems, some $\mathrm{CH}_{4}$ is formed (Table 3), although the equilibrium model does not predict significant amounts of it (Jarungthammachote \& Dutta, 2007). An explanation for this may be that the assumptions used in the model, such as ideal behavior of the gases and perfect mixture, and that the system reaches equilibrium are not totally satisfied, resulting in a difference between the experimental and predicted values. As stated by Fournel et al. 2015, the formation of $\mathrm{CH}_{4}$ is not thermodynamically favorable in equilibrium at higher temperatures, since the Gibbs energy of formation of $\mathrm{CH}_{4}$ is positive $\left(\Delta \mathrm{G}_{\mathrm{f}_{\mathrm{CH}}}^{\mathrm{o}} \approx 24800 \mathrm{~J} / \mathrm{mol}\right)$. The formation of $\mathrm{CO}$ $\left(\Delta \mathrm{G}_{\mathrm{f}_{\mathrm{CO}}}^{\mathrm{o}} \approx-205589 \mathrm{~J} / \mathrm{mol}\right)$ and $\mathrm{CO}_{2}\left(\Delta \mathrm{G}_{\mathrm{f}_{\mathrm{CO}_{2}}}^{\mathrm{o}} \approx-393325\right.$ $\mathrm{J} / \mathrm{mol}$ ) are more favored, as they contribute more to the minimization of the Gibbs energy of the system than the formation of $\mathrm{CH}_{4}$ (Fournel et al., 2015). In order to improve the model accuracy, the amount of $\mathrm{CH}_{4}$ was fixed to a value corresponding to the average of 11 sets of experimental data, which corresponds to a molar fraction of 1.66 (Jarungthammachote \& Dutta, 2007). A comparison of the obtained results is shown in Table 3. 
TABLE 3. Experimental and predicted values of the syngas composition from sawdust gasification.

\begin{tabular}{|c|c|c|c|c|c|c|c|c|}
\hline & \multirow{2}{*}{$\begin{array}{c}\text { Experimental } \\
\text { values } \\
1 \\
\text { (Altafini et al., } \\
2003 \text { ) }\end{array}$} & \multicolumn{3}{|c|}{ Models by other authors } & \multicolumn{4}{|c|}{ Models developed in this study } \\
\hline & & $\begin{array}{c}2 \\
\text { (Altafini et } \\
\text { al., 2003) }\end{array}$ & $\begin{array}{c}3 \\
\text { (Jarungthammachote } \\
\text { \& Dutta, 2007)* }\end{array}$ & $\begin{array}{c}4 \\
\text { (Fournel et } \\
\text { al., 2015)* }\end{array}$ & $\begin{array}{c}5 \\
\text { This study } \\
\text { (No C(s) } \\
\text { formed) } \\
\end{array}$ & $\begin{array}{c}6 \\
\text { This study } \\
\text { (No C(s) } \\
\text { formed)* }\end{array}$ & $\begin{array}{c}7 \\
\text { This study } \\
\text { (With C(s) } \\
\text { formation) } \\
\end{array}$ & $\begin{array}{c}8 \\
\text { This study } \\
\text { (With C(s) } \\
\text { formation)* }\end{array}$ \\
\hline $\mathrm{CH}_{4}$ & 2.31 & 0 & 1.66 & 1.66 & 0.03 & 1.66 & 0.01 & 1.66 \\
\hline $\mathrm{CO}$ & 20.14 & 19.7 & 23.34 & 21.47 & 27.11 & 25.32 & 21.16 & 20.16 \\
\hline $\mathrm{CO}_{2}$ & 12.06 & 10.15 & 9.82 & 11.14 & 7.43 & 8.87 & 11.5 & 12.56 \\
\hline $\mathrm{H}_{2}$ & 14.00 & 20.06 & 18.24 & 18.83 & 22.8 & 19.93 & 21.05 & 18.39 \\
\hline $\mathrm{N}_{2}$ & 50.79 & 50.1 & 46.93 & 46.9 & 42.63 & 44.21 & 46.28 & 47.23 \\
\hline RMSE & - & 3.05 & 3.12 & 2.88 & 6.62 & 5.46 & 3.92 & 2.55 \\
\hline
\end{tabular}

Note: ${ }^{*} \mathrm{CH}_{4}$ amount fixed to the average experimental value obtained by Jarungthammachote \& Dutta (2007).

The results obtained using [eq. (10)] as the objective function were omitted from the table because they showed RMSE values of 19.13 (using species described in Equation 1) and 12.82 (using species described in Equation 2). It can be concluded that [eq. (13)] is the objective function that shows better results for the gasification syngas prediction.

There was an overestimation of $\mathrm{H}_{2}$ formation and an underestimation of $\mathrm{CH}_{4}$ formation by the equilibrium model. Fixing the value of $\mathrm{CH}_{4}$ reduces the estimated amount of $\mathrm{H}_{2}$ and increases the $\mathrm{CO}_{2}$, making the estimation closer to the experimental values, as shown by the RMSE values.

The model in column 8 (using Equation 2 as input) has the lowest root-mean-square error in the prediction of syngas composition. The models developed by Jarungthammachote \& Dutta (2007) and Fournel et al. (2015) are based on Equation 1 (which does not consider char formation). Although the models show similar rootmean-square errors, it can be seen from the results in Table 1 that the char is present in significant amounts, and the slightly better accuracy of the model can be attributed to the formation of $\mathrm{C}_{(\mathrm{s})}$ (Gambarotta et al., 2017).
The results show that the equilibrium model is a good approximation of the gasification system, with good accuracy in predicting the syngas composition. Gasification systems are typically at high temperatures and good mixture rates, which favor the system to achieve the equilibrium state.

\section{Prediction of char formation}

After validating the syngas prediction, an analysis of the prediction of char formation was performed on models obtained by using eqs ((2) and ( () (with fixed and unfixed $\mathrm{CH}_{4}$ amount), which showed better agreement with experimental results.

Table 4 shows a comparison between the results for the char conversion calculated by this study and that calculated by the correlations given by eqs (15) and (16). The conversions $\Phi$ and $\beta$ given by the model were calculated by the $\mathrm{C}_{(\mathrm{s})}$ fractions given by the estimated equilibrium composition, and the correlations were estimated by the ER value, which was ER $=0.31355$ for the experimental run by Altafini et al., (2003).

TABLE 4. Comparison of the predicted char formation.

\begin{tabular}{lcc}
\hline Correlations & $\begin{array}{c}\text { This study } \\
\text { Eq. } 2 \text { and } 13\end{array}$ & $\begin{array}{l}\text { This study } \\
\text { Eq. 2 and 13* }\end{array}$ \\
\hline 0.054 (Eq. 15) & 0.0477 & 0.040 \\
0.821 (Eq. 16) & 0.855 & 0.881 \\
\hline
\end{tabular}

Note: *Model with $\mathrm{CH}_{4}$ amount fixed to the average experimental value obtained by Jarungthammachote \& Dutta (2007).

The results show that, although the modified model with a fixed amount of $\mathrm{CH}_{4}$ showed better accuracy for the prediction of syngas composition, the unmodified model showed a better prediction of char formation. In order to investigate the effect of the moisture content of biomass on the carbon conversion,
Altafini et al., (2003) conducted an experimental study of the effect, with biomass moisture ranging from $0 \%$ to $30 \%$. The results obtained experimentally were compared with those simulated by this model using eqs (2) and (13), which showed better prediction of the syngas. The results are shown in Figure 1. 


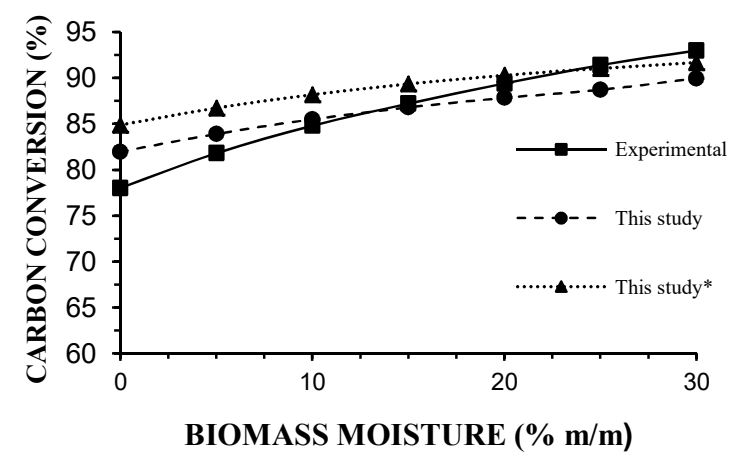

FIGURE 1. Comparison between experimental and predicted effect of moisture on carbon prediction.

*Model with $\mathrm{CH}_{4}$ amount fixed to the average experimental value obtained by Jarungthammachote and Dutta (2007).

The model shows a satisfactory prediction of the carbon conversion, especially for intermediate values of moisture content $(5-20 \%)$. The unmodified model (without fixing the $\mathrm{CH}_{4}$ amount) showed better prediction of the char conversion than the modified model. Thus, both equilibrium models can be used for the gasification modeling: the unmodified model for a better prediction of carbon conversion and the modified model for the prediction of syngas composition.

\section{CONCLUSIONS}

The present study demonstrated the applicability of Gibbs energy minimization to predict gaseous emissions from biomass gasification. The model does not require much detailed information about reactions and other conditions and can predict the composition of the system with good accuracy. From the comparison of the results for the two reaction equations, it can be stated that the formation of solid carbon cannot be neglected (molar fraction of $4-5 \%$, for this study), since even in ideal cases, there is $\mathrm{C}_{(\mathrm{s})}$ in the equilibrium products. The model showed better prediction accuracy when compared to the other models that did not account for char formation, leading to the conclusion that the $\mathrm{C}_{(\mathrm{s})}$ formation can be taken into account in equilibrium models with a reasonably good prediction of the carbon conversion.

This type of model can help to evaluate the suitability of gasification of any biomass with known composition and moisture content, reducing the need for experimental tests. The model could be used to simulate other thermochemical processes, such as combustion and pyrolysis (Li et al., 2004; Mozafari et al., 2017), but the results could be less accurate since these processes have poorer mixing than gasification, making it more difficult for the system to achieve the equilibrium state.

\section{ACKNOWLEDGEMENTS}

The authors thank FAPEMIG - Fundação de Amparo à Pesquisa do Estado de Minas Gerais (EDITAL 01/2016 Demanda Universal - TEC - APQ-00914-16) for the financial support provided for this work.

\section{REFERENCES}

Altafini CR, Wander PR, Barreto RM (2003) Prediction of the working parameters of a wood waste gasifier through an equilibrium model. Energy Conversion and Management 44:2763-2777. DOI: http://dx.doi.org/10.1016/S0196-8904(03)00025-6

Aydin ES, Yucel O, Sadikoglu H (2017) Development of a semi-empirical equilibrium model for downdraft gasification systems. Energy 130:86-98. DOI: http://dx.doi.org/10.1016/j.energy.2017.04.132

Baratieri M, Baggio P, Fiori L, Grigiante M (2008) Biomass as an energy source: Thermodynamic constraints on the performance of the conversion process. Bioresource Technology 99:7063-7073. DOI:

http://dx.doi.org/10.1016/j.biortech.2008.01.006

Demirbas A (2005) Potential applications of renewable energy sources, biomass combustion problems in boiler power systems and combustion related environmental issues. Progress in Energy and Combustion Science 31(2):171-192. DOI:

http://dx.doi.org/10.1016/j.pecs.2005.02.002

Fournel S, Marcos B, Godbout S, Heitz M (2015)

Predicting gaseous emissions from small-scale combustion of agricultural biomass fuels. Bioresource Technology 179:165-172. DOI:

http://dx.doi.org/10.1016/j.biortech.2014.11.100

Gambarotta A, Morini M, Zubani A (2017) A nonstoichiometric equilibrium model for the simulation of the biomass gasification process. Applied Energy January 227:1-9. DOI:

http://dx.doi.org/10.1016/j.apenergy.2017.07.135

Jarungthammachote S, Dutta A (2007) Thermodynamic equilibrium model and second law analysis of a downdraft waste gasifier. Energy 32:1660-1669. DOI:

http://dx.doi.org/10.1016/j.energy.2007.01.010

Jarungthammachote S, Dutta A (2008) Equilibrium modeling of gasification: Gibbs free energy minimization approach and its application to spouted bed and spout-fluid bed gasifiers. Energy Conversion and Management 49:1345-1356. DOI: http://dx.doi.org/10.1016/j.enconman.2008.01.006

Koukkari P, Pajarre R (2006) Introducing mechanistic kinetics to the Lagrangian Gibbs energy calculation. Computers and Chemical Engineering 30(6-7):1189-1196. DOI: http://dx.doi.org/10.1016/j.compchemeng.2006.03.001

Li XT, Grace JR, Lim CJ, Watkinson AP, Chen HP, Kim JR (2004) Biomass gasification in a circulating fluidized bed. Biomass and Bioenergy 26(2):171-193. DOI: http://dx.doi.org/10.1016/S0961-9534(03)00084-9

Mcbride J, Reno A (1993) Coefficients for calculating thermodynamic anel transport properties of individual species. Cleveland, NASA Lewis Research Center. (NASA Technical Memorandum 4513) 
Mendiburu AZ, Carvalho Jr. JA, Zanzi R, Coronado CR, Silveira JL (2014) Thermochemical equilibrium modeling of a biomass downdraft gasifier: Constrained and unconstrained non-stoichiometric models. Energy 71:624637. DOI: http://dx.doi.org/10.1016/j.energy.2014.05.010

Mozafari A, Tabrizi FF, Farsi M, Mousavi SAHS (2017) Thermodynamic modeling and optimization of thermolysis and air gasification of waste tire. Journal of Analytical and Applied Pyrolysis. 126:415-422. DOI: http://dx.doi.org/10.1016/j.jaap.2017.04.001

Rajh B, Yin C, Samec N, Hriberšek M, Zadravec M (2016) Advanced modelling and testing of a 13 MWth waste wood-fired grate boiler with recycled flue gas. Energy Conversion and Management 125:230-241. DOI: http://dx.doi.org/10.1016/j.enconman.2016.02.036

Roni MS, Chowdhury S, Mamun S, Marufuzzaman M, Lein W, Johnson S (2017) Biomass co-firing technology with policies, challenges, and opportunities: A global review. Renewable and Sustainable Energy Reviews 78:1089-1101. DOI: http://dx.doi.org/10.1016/j.rser.2017.05.023

Saidur R, Abdelaziz EA, Demirbas A, Hossain MS, Mekhilef S (2011) A review on biomass as a fuel for boilers. Renewable and Sustainable Energy Reviews 15(5):2262-2289. DOI:

http://dx.doi.org/10.1016/j.rser.2011.02.015
Silveira JC, Costa AOS da, Costa Jr. EF da (2017) Modeling of basil essential oil extraction with variable diffusion. Engenharia Agrícola 37(4):717-726. DOI: http://dx.doi.org/10.1590/1809-4430Eng.Agric.v37n4p717-726/2017

Singh D, Dar BA, Kim DS (2016) KKT optimality conditions in interval valued multiobjective programming with generalized differentiable functions. European Journal of Operational Research 254(1):29-39. DOI: http://dx.doi.org/10.1016/j.ejor.2016.03.042

Siqueira ÁJH, Costa AOS da, Costa Jr EF da (2012) Modeling and simulation of forced-air cooling of strawberries using variable convective coefficient. Engenharia Agrícola 32(1):164-173.

Smith JM, Van Ness HC, Abbott MM, Swihart MT (2017) Introduction to chemical engineering thermodynamics. McGraw-Hill, 8th ed.

Sundman B, Lu XG, Ohtani H (2015) The implementation of an algorithm to calculate thermodynamic equilibria for multi-component systems with non-ideal phases in a free software. Computational Materials Science. 101:127-137. DOI: http://dx.doi.org/10.1016/j.commatsci.2015.01.029

Verma VK, Bram S, Gauthier G, Ruyck J de (2011) Evaluation of the performance of a multi-fuel domestic boiler with respect to the existing European standard and quality labels: Part-1. Biomass and Bioenergy 35(1):80-89. DOI: http://dx.doi.org/10.1016/j.biombioe.2010.08.028 